\title{
Human blood glutathione (GSH) as a tool for arsenic detoxification
}

\author{
Naseem Ullah*, Muhammad Farid Khan and Muhammad Mukhtiar \\ Department of Pharmaceutical Chemistry, Gomal University, D. I. Khan, KPK Pakistan. \\ Accepted 12 September, 2011
}

\begin{abstract}
Arsenic is a major threat to a large part of the population due to its carcinogenic nature. The toxicity of arsenic emerges from glutathione (GSH) depletion caused by arsenic with unknown mechanism. GSH depletion leads to apoptosis, lipid peroxidation and eventual cell death. The present study was designed to provide insight into the extent of changes in GSH level by arsenic. Plasma and cytosolic fraction were investigated for determination of changes in GSH metabolic status caused by arsenic in the form of arsenic trioxide (ATO). The depletion of GSH level was found to be positively correlated with increasing parameters, that is, arsenic concentration and time of incubation. Our findings show that changes in GSH status produced by arsenic could be due to adduct (As-(SG) $)_{3}$ ) formation. This change in GSH metabolic status provides information regarding mechanism of toxicity of ATO. These findings are important for the rational design of antidote for the prevention of arsenic induced toxicity.
\end{abstract}

Key words: Arsenic trioxide (ATO), glutathione (GSH), dithiobisnitrobenzoic acid (DTNB), plasma, cytosolic fraction (C.F).

\section{INTRODUCTION}

Arsenic (As) is a widespread environmental toxin. It enters the organisms by dermal contact, inhalation, or ingestion of contaminated drinking water and affects nearly entire organ systems of the body (Ratnaike, 2003). Arsenic compounds are quite effectively incorporated from the gastrointestinal tract. Arsenate (V) is absorbed to roughly $60 \%$, trivalent arsenic to $80 \%$ and natural organoarsenicals to nearly $100 \%$ (Zielhuis and Wibowo, 1984).

Glutathione $(\mathrm{GSH})$ is the most prevalent low molecular weight cellular thiol in mammalian cells. In addition to having a major cellular role in oxidative status, there is an important function of GSH in sequestering toxic, electrophilic xenobiotics (Boyland and Chasseaud, 1969; Chasseaud, 1976). Nucleophilic reactivity of GSH is based on conjugation of its thiol group with electrophilic compounds (Commandeur et al., 1995). This characteristic underlies its potent antioxidant action and

*Corresponding author. E-mail: naseemscholar@gmail.com. Tel: 03239989477. enzyme cofactor properties, and supports a complex thiol-exchange system, which hierarchically regulates cell activity. GSH levels in human tissues normally range from 0.1 to 10 millimolar $(\mathrm{mM})$, most concentrated in the liver (up to $10 \mathrm{mM}$ ) and in the spleen, kidney, lens, erythrocytes, and leukocytes (Bremer et al., 1981). Oxidative stressors that can deplete GSH include ultraviolet and other radiation (Cai et al., 2000), viral infections (Kidd, 1997; Look et al., 1997), environmental toxins, household chemicals, and heavy metals (Kidd, 1997) surgery, inflammation, burns, septic shock (Luo et al., 1998; Spies et al., 1994) and dietary deficiencies of GSH precursors and enzyme cofactors (Whitcomb and Block, 1994).

Most of the toxicological features of arsenic described here may be explained by a high affinity to sulfhydryls resulting in an inhibition of a great number of enzymes. Investigations at the cellular and molecular levels reveal that As enhances production of reactive oxygen species (like, superoxide and hydrogen peroxide), causes lipid peroxidation, enhances oxidation of proteins, enzymes as well as DNA (Yamauchi et al., 2004; Kitchin, 2001), disrupts mitosis and promotes apoptosis (States et al., 
2002). These data suggest that ATO-induced apoptosis is attributed primarily through the depletion of GSH.

Glutathione and enzymes related to GSH synthesis comprise a system that maintains the intracellular reducing environment and acts as a primary defense against excessive generation of harmful ROS. One of the important mechanisms of arsenic induced disorders is its ability to bind with sulfydryl group (-SH) containing molecules. Trivalent inorganic arsenicals, such as arsenite, readily react with reduced glutathione (GSH) and cysteine and decrease their bio-availability (Thomas et al., 2001). Our study will further provide the detailed information regarding the extent of changes occurring in GSH level in plasma and cytosolic fraction, when subjected to different ATO concentrations and different time fixations.

\section{MATERIALS AND METHODS}

The materials includes L. glutathione (GSH) (Fluka), DTNB (Sigma), sodium hydroxide (Fluka AG), sodium chloride (Merck), disodium edetate (Riedel Dehean AG Sleeze Hannover), potassium dihydrogen phosphate (Merck), $\mathrm{HCl} 35 \%$ (Kolchlight), arsenic trioxide (Across, Belgium), distilled water (Double Refined), chloroform (Merck), ethanol (Merck), spectrophotometer: UV. visible, 1601 (Schimadzu, Japan), pH meter: Model NOV-210 (Nova Scientific Company Ltd. Korea), analytical balance AX 200 (Schimadzu, Japan) centrifuge $\mathrm{H}-200$ (Kokusan Ensink Company Japan), Eppendolf's tubes (Plastic, 101) oven: Memmert model U30,854 (Schwa Bach, Germany) and magnetic stirrer. Were purchased from local market.

\section{Preparation of stock solution}

To make $0.9 \%-\mathrm{NaCl}$ solution, $90 \mathrm{mg}$ of pharmaceutical grade $\mathrm{NaCl}$ was added to $\mathrm{D} / \mathrm{W}$ quantity sufficient (q.s.) $100 \mathrm{ml}$. Arsenic trioxide (ATO), $2 \mathrm{mM}$ solution contained $19.8 \mathrm{mg}$ of ATO in D/W q.s. $50 \mathrm{ml}$, which was again gradually diluted to get 10 different $(0.2,0.4,0.6$, $0.8,1.00,1.2,1.4,1.6,1.8$ and $2.00 \mathrm{mM}$ ) concentrations of ATO. GSH $(1 \mathrm{mM})$ standard solution was obtained through dissolving $15.375 \mathrm{mg}$ of $\mathrm{GSH}$ in $50 \mathrm{ml}$ of phosphate buffer (pH 7.6). $19.8 \mathrm{mg}$ of 5-5, dithiobis 2-nitrobenzoic acid (DTNB) was added to phosphate buffer ( $\mathrm{pH} 7.6)$ to get $50 \mathrm{ml}$ of $1 \mathrm{mM}$ solution of DTNB.

\section{Isolation of plasma and cytosolic fraction}

\section{Plasma}

Fresh venous blood $(12 \mathrm{ml})$ was collected from a healthy human volunteer in a heparinized test tube. ESR of this blood sample was $12 \mathrm{~mm}$, clotting time $4 \mathrm{~min}$ and $\mathrm{Hb}$ was $15.4 \mathrm{~g} / \mathrm{dl}$. Hematocrit included blood cells $45 \%$, plasma $55 \%$ and RBCs count was 5.2 million $/ \mathrm{mm}^{3}$. From this blood sample, each time, $1 \mathrm{ml}$ was taken and added to $1 \mathrm{ml}$ of each of the 10 concentrations of the ATO solution resulting 10 mixtures having different concentrations of ATO. All the mixtures were shaken and incubated for $5 \mathrm{~min}$. Each of these $2 \mathrm{ml}$ samples containing blood and ATO in 1:1 ratio were centrifuged at $10,000 \mathrm{rpm}$ for $5 \mathrm{~min}$. The respective supernatant (Plasma) was carefully pipetted upto $0.8 \mathrm{ml}$ from each mixture and transferred to separate sample tubes. The remaining packed cells fractions were processed further for the collection of lysate or cytosolic fraction.

\section{Cytosolic fraction}

The packed cells fractions were washed twice with $0.9 \% \mathrm{NaCl}$ (isotonic) solution and then added drop wise $\mathrm{D} / \mathrm{W}$ equal in volume to lyse RBCs. Then $0.6 \mathrm{ml}$ of cold mixture of chloroform and ethanol $(3: 5 \mathrm{v} / \mathrm{v})$ was incorporated at $0^{\circ} \mathrm{C}$ to precipitate hemoglobin. The resultant fractions were centrifuged and pale yellow supernatant (Cytosolic fraction) was collected from each mixture and transferred to separate sample tubes.

\section{Plasma and cytosolic fraction controls}

Plasma control was prepared through mixing blood and $0.9 \% \mathrm{NaCl}$ solution in $1: 1$ ratio and then centrifuged to collect plasma portion as before.

Control for cytosolic fraction was prepared through mixing blood and $0.9 \% \mathrm{NaCl}$ solution in $1: 1$ ratio and then centrifuged to collect cytosolic fraction portion as before.

\section{Experimental design}

Through centrifugation, plasma and cytosolic fraction were collected in separate sample tubes. The concentration dependent effect of ATO $(0.2,0.4,0.6,0.8,1.00,1.2,1.4,1.6,1.8$ and 2.00 $\mathrm{mM}$ ) on GSH level was studied in plasma and cytosolic fraction each. The final ATO concentration (in each 10 samples of plasma and 10 samples of cytosolic fraction) was 100, 200, 300, 400, 500, $600,700,800,900$ and $1000 \mu \mathrm{M}$. Data for effect of ATO on GSH level at different time fixations $(00,30,60$ and $90 \mathrm{~min})$ was also collected. The time course studies were carried for each concentration of ATO, from 100 to $1000 \mu \mathrm{M}$.

\section{Experimental parameters}

Assay of plasma and cytosolic fraction incubated with different ATO concentrations and at different time fixations was made for estimation of effective toxicity marker compound, glutathione, in reduced form (GSH).

\section{Determination of GSH concentration}

The reduced glutathione level was determined by the method of Ellman (1959).

$0.2 \mathrm{ml}$ from each of the samples of the plasma/cytosolic fraction (having different ATO concentration) was added to $2.3 \mathrm{ml}$ of phosphate buffer ( $\mathrm{pH} 7.6)$. Then $0.5 \mathrm{ml}$ of reagent (DTNB) was added. The absorbance was determined at $412 \mathrm{~nm}$ against respective control, where ATO had not been added. The concentration of GSH was expressed as $\mu \mathrm{M}$.

\section{RESULTS}

\section{Assay of plasma-GSH level}

Change in plasma-GSH level at different ATO concentrations: GSH level was determined in different plasma samples, each one having varied ATO concentrations $(100,200,300,400,500,600,700,800,900$ and 1000 
Table 1. Effect of Different concentrations of arsenic trioxide $(0.2$ to $2 \mathrm{mM})$ on the chemical status of glutathione (GSH) with time in plasma (arsenic trioxide was injected into whole blood before its separation and incubated for $30 \mathrm{~min}$ ).

\begin{tabular}{|c|c|c|c|c|c|c|c|c|c|}
\hline $\mathrm{S} / \mathrm{N}$ & $\begin{array}{c}\text { Concentration } \\
\text { of arsenic } \\
\text { trioxide }(\mu \mathrm{M})\end{array}$ & $\begin{array}{c}\text { Average } \\
\text { ABS at } 0 \\
\text { min }\end{array}$ & $\begin{array}{c}\text { Concentration } \\
(\mu \mathrm{M}) \text { of } \mathrm{GSH} \\
\text { at } 0 \mathrm{~min}\end{array}$ & $\begin{array}{c}\text { Average } \\
\text { ABS at } 30 \\
\text { min }\end{array}$ & $\begin{array}{c}\text { Concentration } \\
(\mu \mathrm{M}) \text { of } \mathrm{GSH}, \\
\text { at } 30 \mathrm{~min}\end{array}$ & $\begin{array}{c}\text { Average } \\
\text { ABS at } 60 \\
\text { min }\end{array}$ & $\begin{array}{c}\text { Concentration } \\
(\mu \mathrm{M}) \text { of GSH, } \\
\text { at } 60 \mathrm{~min}\end{array}$ & $\begin{array}{c}\text { Average } \\
\text { ABS at } 90 \\
\text { min }\end{array}$ & $\begin{array}{c}\text { Concentration } \\
(\mu \mathrm{M}) \text { of } \mathrm{GSH} \text {, at } \\
90 \mathrm{~min}\end{array}$ \\
\hline 1 & 100 & 0.442 & 38.1 & 0.431 & 37.2 & 0.413 & 35.7 & 0.394 & 34.2 \\
\hline 2 & 200 & 0.393 & 34.1 & 0.378 & 32.9 & 0.362 & 31.6 & 0.349 & 30.5 \\
\hline 3 & 300 & 0.362 & 31.6 & 0.344 & 30.1 & 0.327 & 28.7 & 0.312 & 27.5 \\
\hline 4 & 400 & 0.328 & 28.8 & 0.315 & 27.7 & 0.303 & 26.7 & 0.287 & 25.4 \\
\hline 5 & 500 & 0.303 & 26.7 & 0.288 & 25.5 & 0.263 & 23.5 & 0.251 & 22.5 \\
\hline 6 & 600 & 0.284 & 25.2 & 0.267 & 23.8 & 0.249 & 22.3 & 0.234 & 21.1 \\
\hline 7 & 700 & 0.261 & 23.3 & 0.243 & 21.8 & 0.227 & 20.5 & 0.219 & 19.8 \\
\hline 8 & 800 & 0.239 & 21.5 & 0.216 & 19.6 & 0.189 & 17.4 & 0.172 & 16.0 \\
\hline 9 & 900 & 0.217 & 19.7 & 0.194 & 17.8 & 0.178 & 16.5 & 0.157 & 14.8 \\
\hline 10 & 1000 & 0.196 & 18.0 & 0.175 & 16.2 & 0.161 & 15.1 & 0.143 & 13.6 \\
\hline \multicolumn{2}{|c|}{ Plasma control } & 0.647 & 54.9 & 0.647 & 54 & 0.647 & 54.9 & 0.647 & 54.9 \\
\hline
\end{tabular}

$\mu \mathrm{M})$. The spectrophotometric analysis showed marginal drop in GSH level $(38.1 \mu \mathrm{M})$ with the initial ATO concentration, that is, $100 \mu \mathrm{M}$ compared to the control plasma-GSH $(54.9 \mu \mathrm{M})$. The GSH level seemed continuously declining in other plasma samples which contained increasing ATO concentrations. The maximum used ATO concentration $(1000 \mu \mathrm{M})$ brought drop in $\mathrm{GSH}$ level up to $18.00 \mu \mathrm{M}$ compared to the control plasma-GSH (54.9 $\mu \mathrm{M})$ as shown in Table 1 and Figure 1.

Change in plasma-GSH level by ATO at different time fixations: Each plasma sample having one of the different ATO concentrations $(100$ to $1000 \mu \mathrm{M})$ was incubated upto different fixations time (0-, 30-, 60- and 90-min). By extending incubation period, the plasma-GSH level was further decreasing, the maximum decrease in plasma-GSH level being with the maximum provided time as shown in Table 1 and Figure 2.

\section{Assay of C.F-GSH level}

Change in C.F-GSH level at different ATO concentrations: Different C.F samples were also assayed for GSH determination containing different ATO concentrations $(100,200,300,400$, $500,600,700,800,900$ and $1000 \mu \mathrm{M})$. C.F-GSH level showed prominent drop $(37.6 \mu \mathrm{M})$ with the initial of the used concentration $(100 \mu \mathrm{M})$ compared to the control C.F-GSH $(67.5 \mu \mathrm{M})$. Increasing ATO concentration resulted in gradual decrease in C.F-GSH level, highest decrease $(10.8 \mu \mathrm{M})$ being with the maximum of the used ATO concentration $(1000 \mu \mathrm{M})$ as shown in Table 2 and Figure 3.

Change in C.F-GSH level by ATO at different time fixations: C.F samples having different ATO concentrations were incubated at different time fixations (0-, 30-, 60- and 90-min) and were analyzed for change in GSH level. The pattern of lowering C.F-GSH level seemed to be associated with the provision of more time as shown in Table 2 and Figure 4.

\section{DISCUSSION}

We have studied the effect of arsenic trioxide (ATO) on GSH level in plasma and cytosolic fraction of human venous blood spectrophotometrically. The concentrations of ATO used in the present study ranged from 100 to $1000 \mathrm{uM}$ ATO. The effect of arsenic on the chemical and metabolic status of GSH was studied in terms of determination of concentration of GSH at $\lambda$ max $412 \mathrm{~nm}$. This $\lambda \max (412 \mathrm{~nm})$ is being used for the determination of GSH concentration in samples according to Elman's (1959) method.

Thus the interaction of this metal with glutathione in vitro as a model of in vivo reaction will establish further scientific data and will strengthen our knowledge about the toxicological 


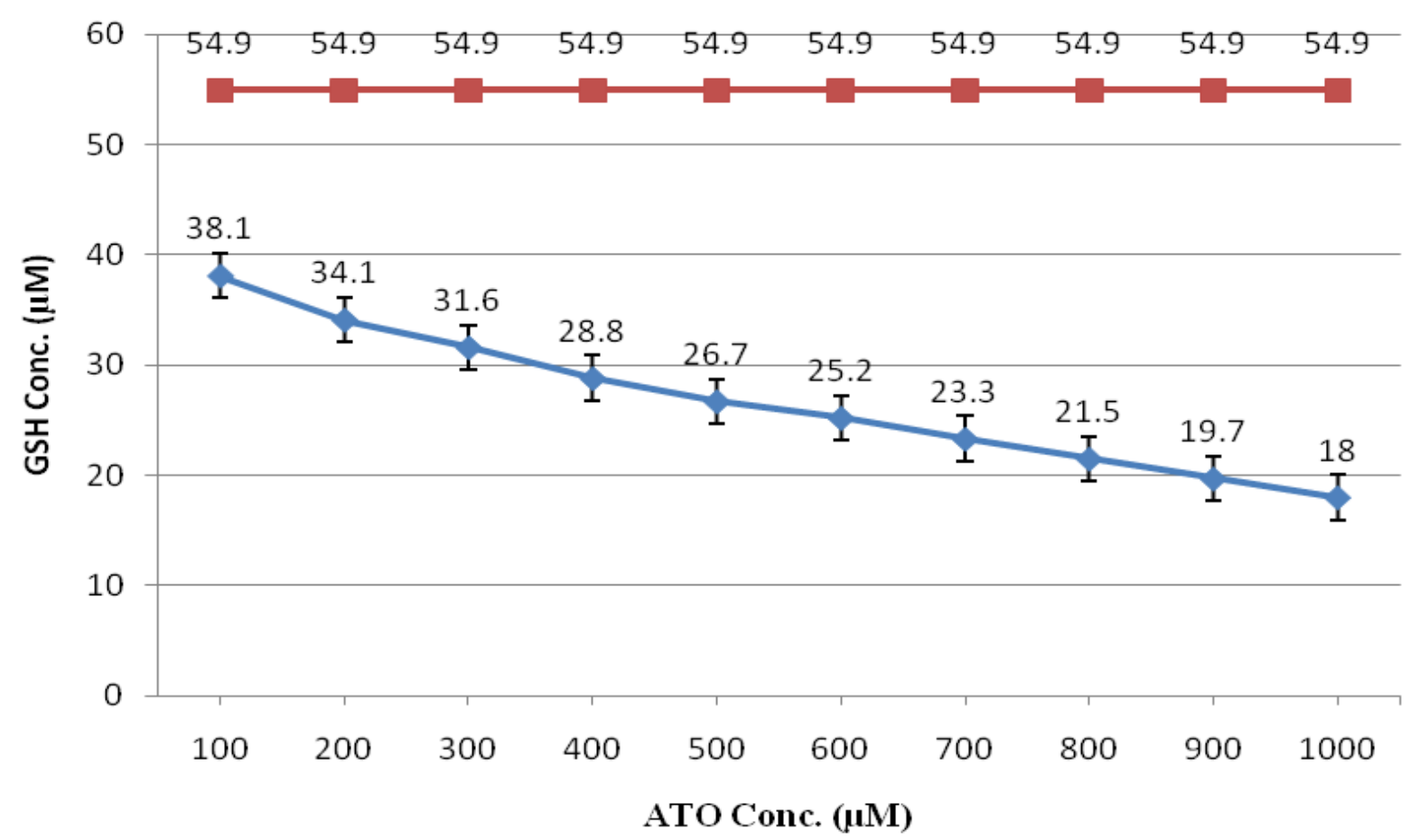

Figure 1. Effect of ATO concentration on plasma GSH content. — Plasma control $(1 \mathrm{ml} 0.9 \% \mathrm{NaCl} / 1 \mathrm{ml}$ of blood); ATO $(100$ to $1000 \mu \mathrm{M})$. Results are the mean \pm SE of 3 experiments of plasma GSH.

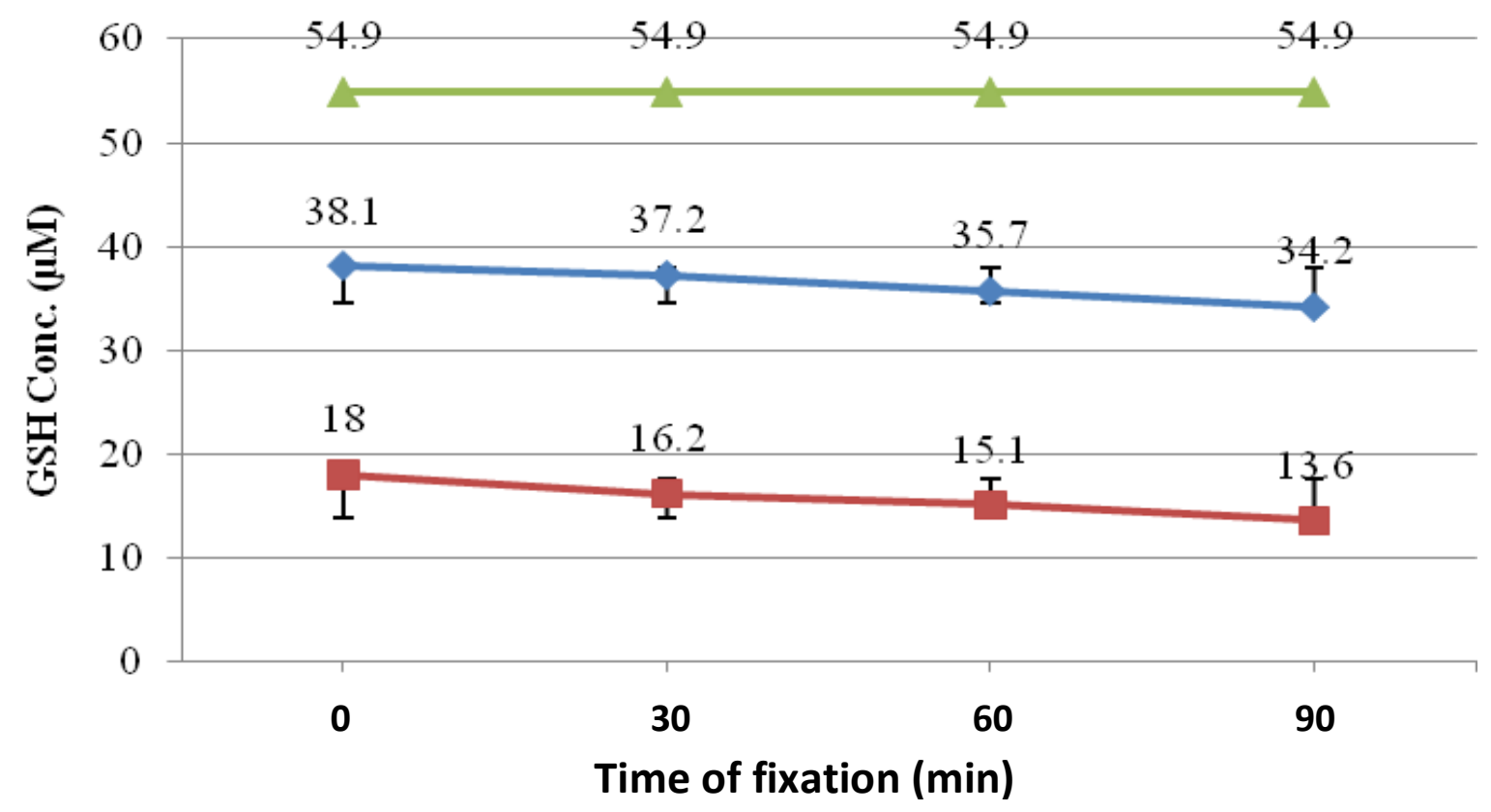

Figure 2. Effect of ATO concentration on the plasma GSH content with time incubation period $(0$ to 90 min); $\Delta$ Plasma control $(1 \mathrm{ml} 0.9 \% \mathrm{NaCl} / 1 \mathrm{ml}$ of blood); ATO $(100 \mu \mathrm{M})$; ATO $(1000 \mu \mathrm{M})$. Results are the mean \pm SE of 3 experiments of plasma GSH

profile of arsenic and the role of GSH in the protection of our body from its harmful effects. According to our findings, the arsenic in the form of arsenic trioxide (ATO) induced the depletion of $\mathrm{GSH}$ in a dose dependent of 
Table 2. Effect of different concentrations of arsenic trioxide ( 0.2 to $2 \mathrm{mM}$ ) on the chemical status of glutathione (GSH) with time in cytosolic fraction (arsenic trioxide was injected into whole blood before its separation and incubated for $30 \mathrm{~min}$ )

\begin{tabular}{|c|c|c|c|c|c|c|c|c|c|}
\hline $\mathbf{S} / \mathbf{N}$ & $\begin{array}{l}\text { Concentration } \\
\text { of arsenic } \\
\text { trioxide }(\mu \mathrm{M})\end{array}$ & $\begin{array}{c}\text { Average } \\
\text { ABS at } 0 \mathrm{~min}\end{array}$ & $\begin{array}{c}\text { Concentration } \\
(\mu \mathrm{M}) \text { of } \mathrm{GSH}, \\
\text { at } 0 \mathrm{~min}\end{array}$ & $\begin{array}{c}\text { Average } \\
\text { ABS at } 30 \\
\text { min }\end{array}$ & $\begin{array}{l}\text { Concentration } \\
(\mu \mathrm{M}) \text { of } \mathrm{GSH}, \\
\text { at } 30 \mathrm{~min}\end{array}$ & $\begin{array}{c}\text { Average } \\
\text { ABS at } 60 \\
\text { min }\end{array}$ & $\begin{array}{l}\text { Concentration } \\
(\mu \mathrm{M}) \text { of } \mathrm{GSH}, \\
\text { at } 60 \mathrm{~min}\end{array}$ & $\begin{array}{c}\text { Average } \\
\text { ABS at } 90 \\
\text { min }\end{array}$ & $\begin{array}{c}\text { Concentration } \\
(\mu \mathrm{M}) \text { of } \mathrm{GSH} \text {, at } \\
90 \mathrm{~min}\end{array}$ \\
\hline 1 & 100 & 0.436 & 37.6 & 0.421 & 36.4 & 0.404 & 35.0 & 0.381 & 33.1 \\
\hline 2 & 200 & 0.389 & 33.8 & 0.364 & 31.7 & 0.347 & 30.3 & 0.323 & 28.4 \\
\hline 3 & 300 & 0.343 & 30.0 & 0.324 & 28.5 & 0.301 & 26.6 & 0.288 & 25.5 \\
\hline 4 & 400 & 0.304 & 26.8 & 0.279 & 24.8 & 0.261 & 23.3 & 0.238 & 21.4 \\
\hline 5 & 500 & 0.261 & 23.3 & 0.239 & 21.5 & 0.221 & 20.0 & 0.204 & 18.6 \\
\hline 6 & 600 & 0.227 & 20.5 & 0.203 & 18.5 & 0.181 & 16.7 & 0.158 & 14.8 \\
\hline 7 & 700 & 0.194 & 17.8 & 0.172 & 16.0 & 0.149 & 14.1 & 0.131 & 12.6 \\
\hline 8 & 800 & 0.166 & 15.5 & 0.145 & 13.8 & 0.128 & 12.4 & 0.107 & 10.7 \\
\hline 9 & 900 & 0.137 & 13.1 & 0.116 & 11.4 & 0.102 & 10.3 & 0.088 & 9.1 \\
\hline 10 & 1000 & 0.109 & 10.8 & 0.093 & 9.5 & 0.074 & 8.0 & 0.058 & 6.6 \\
\hline CF Control & & 0.800 & 67.5 & 0.800 & 67.5 & 0.800 & 67.5 & 0.800 & 67.5 \\
\hline
\end{tabular}

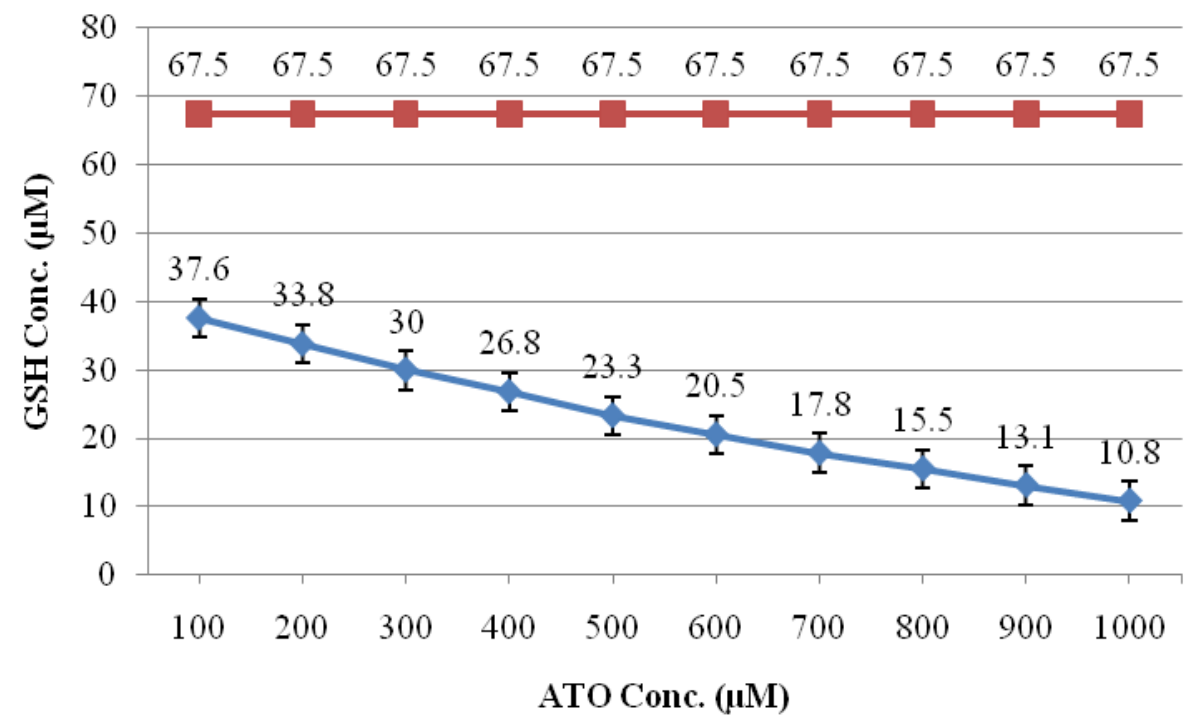

Figure 3. Effect of ATO on cytosolic fraction GSH content; - CF control $(1 \mathrm{ml} 0.9 \%$ $\mathrm{NaCl} / 1 \mathrm{ml}$ of blood); ATO (100 to $1000 \mu \mathrm{M})$. Results are the mean \pm SE of 3 experiments of cytosolic fraction GSH. 


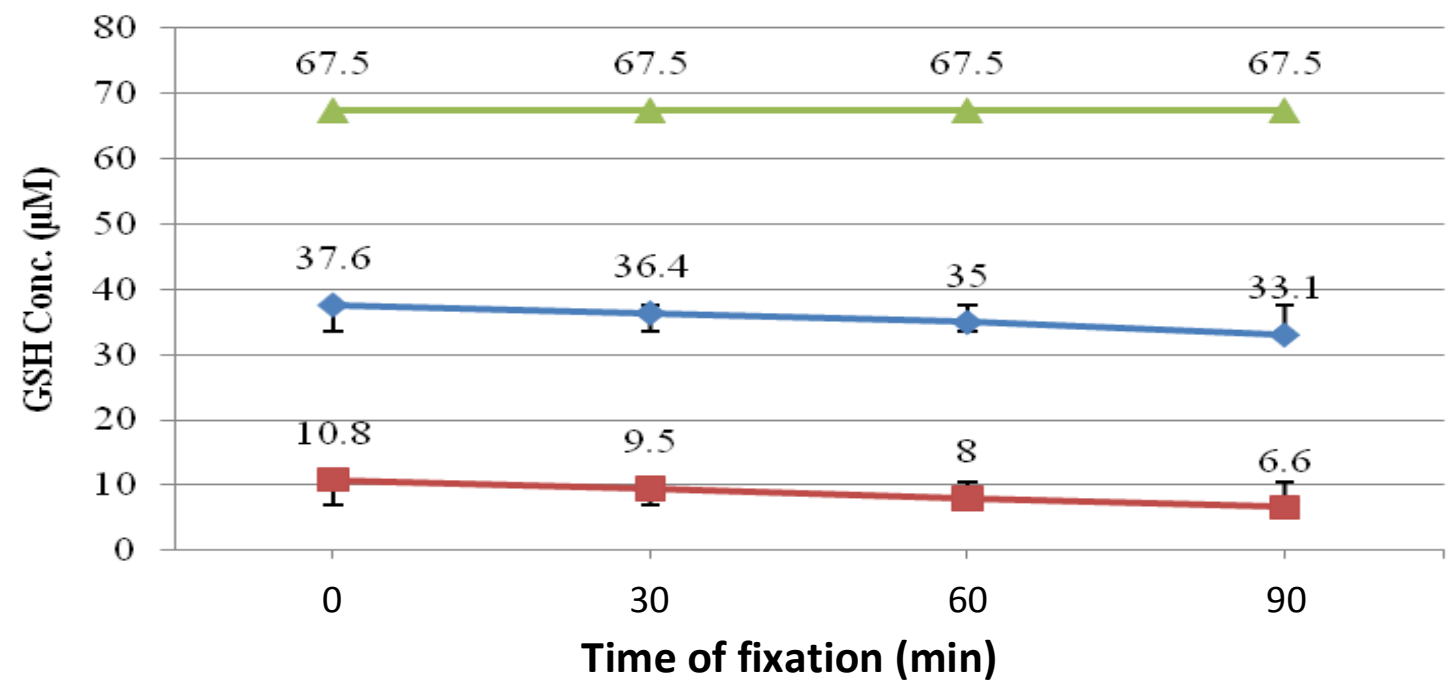

Figure 4. Effect of ATO on cytosolic fraction GSH content with time incubation period (0 to $90 \mathrm{~min}$ ); $\boldsymbol{\Delta} \mathrm{CF}$ control $(1 \mathrm{ml} 0.9 \% \mathrm{NaCl} / 1 \mathrm{ml}$ of blood); ATO $(100 \mu \mathrm{M})$; - ATO $(1000 \mu \mathrm{M})$. Results are the mean \pm SE of 3 experiments of cytosolic fraction GSH

manner. The results also show positive correlation between the exposure of glutathione to the given concentrations of ATO and the depletion of GSH as the time passed from 0 to $90 \mathrm{~min}$.

The fact that arsenic trioxide (ATO) has considerable pharmacological effects prompted us to examine the interaction of ATO with glutathione $(\mathrm{GSH})$, the most important intra and extracellular antioxidant in plasma and cytosolic fraction of healthy human volunteers. Furthermore, little information is available on ATO mechanism of action at the molecular level. Our experimental work proposes the molecular mechanism of action of ATO. Our research hypothesis was that ATO directly or indirectly or through enzymatic or non-enzymatic pathway causes modulation in the status of GSH either to glutathione disulfide (GSSG) or formation of arsenicglutathione (As-SG) complex.

Our results support the hypothesis that incubation and addition of ATO to venous blood, separation of plasma and cytosolic fraction and determination of $\mathrm{GSH}$ decreased the concentration of GSH in these components, one of the characteristics of ATO as an oxidant.

The exact mechanism of action of ATO on GSH metabolic status in this study is not known. However the proposed hypothetical mechanism of action of ATO on $\mathrm{GSH}$ metabolic status is the formation of As- $(\mathrm{SG})_{3}$ complex. This hypothetical mechanism of action and formation of As- $(\mathrm{SG})_{3}$ complex is in agreement with our research work, where antibacterial activity of ATO, GSH and ATO and GSH mixture were examined.

The results indicate that antibacterial activity of ATO was very low (almost Zero), GSSG, GSH were high and ATO and GSH mixture was lower than GSH and higher than ATO (data not shown).

These results indicating that antibacterial activity of
GSH and GSSG were the same and GSH and ATO mixture was very low than GSH and GSSG and ATO had almost Zero, leads to the conclusion that ATO had not caused the oxidation of GSH to GSSG but consistent with the reaction taking place at the active site of $\mathrm{GSH}$ and that is $\mathrm{S}-\mathrm{H}$ group.

Such reaction through a mechanism involving the coordination of As in ATO with the $\mathrm{S}-\mathrm{H}$ group of $\mathrm{GSH}$ with the formation of As-(SG) $)_{3}$ complex is as:

$$
\begin{aligned}
& \mathrm{As}_{2} \mathrm{O}_{3} \longrightarrow 2 \mathrm{As}^{+3}+3 \mathrm{O}^{-2} \\
& 2 \mathrm{As}^{+3}+6 \mathrm{GSH} \longrightarrow 2 \mathrm{As}-(\mathrm{SG})_{3}+3 \mathrm{H}_{2} \mathrm{O}
\end{aligned}
$$

In conclusion, we have examined interaction of ATO with GSH spectrophotometerically and hypothesized the formation of As-(SG) $)_{3}$ complex, which might have clinical implication.

The data provided in this research work is lacking implementation of statistical analysis, as the blood samples were collected from a single healthy volunteer.

\section{REFERENCES}

Boyland E, Chasseaud LF (1969). The role of glutathione and glutathione S-transferases in mercapturic acid biosynthesis. Adv. Enzymol. Relat. Areas Mol. Biol., 32: 173-219.

Bremer HJ, Duran M, Kamerling JP (1981). Glutathione In: Bremer HJ, Duran M, Kamerling JP, et al, eds. Disturbances of Amino Acid Metabolism:Clinical Chemistry and Diagnosis. Baltimore-Munich: Urban and Schwarzenberg. pp. 80-88

Cai J, Nelson KC, Wu M (2000). Oxidative damage and protection of the RPE. Progr. Retinal. Eye Res., 19: 205-221.

Chasseaud LF (1976). Conjugation with glutathione and mercapturic acid excretion, in Glutathione: Metabolism and Function (Arias IM and Jakoby WB eds). Raven Press, New York, pp. 77-114.

Commandeur JNM, Stijntjes GJ, Vermeulen NPE (1995). Enzymes and 
transport systems involved in the formation and disposition of glutathione S-conjugates. Role in bioactivation and detoxication mechanisms of xenobiotics. Pharmacol. Rev., 47: 271-330.

Ellman GL (1959). Tissue sulfhydryl groups. Arch. Biochem. Biophys., 82: $70-77$

Kidd PM (1997). Glutathione: Systemic protectant against oxidative and free radical damage. Altern. Med. Rev., 1: 155-176.

Kitchin KT (2001). Recent advances in arsenic carcinogenesis: Modes of action, animal model systems, and methylated arsenic metabolites. Toxicol. Appl. Pharmacol., 172: 249-261.

Look MP, Rockstroh JK, Rao GS (1997). Serum selenium, plasma glutathione (GSH) and erythrocyte glutathione peroxidase (GSH-Px)levels in asymptomatic versus symptomatic human immunodeficiency virus-1 (HIV-1)-infection. Eur. J. Clin. Nutr., 51: 266-272.

Luo J-L, Hammarqvist F, Andersson K (1998). Surgical trauma decreases glutathione synthetic capacity in human skeletal muscle tissue. Am. J. Physiol., 275: 359-365.

Ratnaike RN (2003). Acute and chronic arsenic toxicity. Postgrad. Med. J., 79: 391-396.

Spies CD, Reinhart K, Witt I (1994). Influence of N-acetylcysteine on direct indicators of tissue oxygenation in septic shock patients: results from a prospective, randomized, double-blind study. Crit. Care Med., 22: $1738-1746$.
States JC, Reiners JJ, Pounds JG, Kaplan DJ, Beauerle BD (2002). Arsenite disrupts mitosis and induces apoptosis in SV40-transformed human skin fibroblasts. Toxicol. Appl. Pharmacol., 180: 83-91.

Thomas DJ, Styblo M, Lin S (2001). The cellular metabolism and systemic toxicity of arsenic. Toxicol. Appl. Pharmacol., 176: 127-144.

Whitcomb DC, Block GD (1994). Association of acetaminophen hepatotoxicity with fasting and ethanol use. JAMA, 272: 1845-1850.

Yamauchi H, Aminaka Y, Yoshida K, Sun G, Pi J (2004). Evaluation of DNA damage in patients with arsenic poisoning: urinary 8hydroxydeoxyguanine. Toxicol. Appl. Pharmacol., 198: 291-296.

Zielhuis RL, Wibowo AAE (1984). Standard setting and metal speciation: arsenic, in: J.O. Nriagu (Ed.),.Changing Metal Cycles and Human Health, Dahlem Konferenzen, Springer, Berlin, pp. 323-344. 